\title{
CRIME AND GENDER SEGREGATION: EVIDENCE FROM THE BOGOTA "PICO Y GENERO" LOCKDOWN
}

\author{
Brian G. Knight \\ Maria Mercedes Ponce de Leon \\ Ana Tribin \\ Working Paper 28686 \\ http://www.nber.org/papers/w28686 \\ NATIONAL BUREAU OF ECONOMIC RESEARCH \\ 1050 Massachusetts Avenue \\ Cambridge, MA 02138 \\ April 2021
}

The findings, interpretations, and conclusions in this paper are entirely those of the authors and do not necessarily represent the views of the organizations to which the authors are affiliated. Thanks to Gabriela Diaz for helpful research assistance. The views expressed herein are those of the authors and do not necessarily reflect the views of the National Bureau of Economic Research.

NBER working papers are circulated for discussion and comment purposes. They have not been peer-reviewed or been subject to the review by the NBER Board of Directors that accompanies official NBER publications.

(C) 2021 by Brian G. Knight, Maria Mercedes Ponce de Leon, and Ana Tribin. All rights reserved. Short sections of text, not to exceed two paragraphs, may be quoted without explicit permission provided that full credit, including (C) notice, is given to the source. 
Crime and Gender Segregation: Evidence from the Bogota "Pico y Genero" Lockdown

Brian G. Knight, Maria Mercedes Ponce de Leon, and Ana Tribin

NBER Working Paper No. 28686

April 2021

JEL No. J1,K4,O1

\begin{abstract} increase crime.

Brian G. Knight

Brown University

Department of Economics, Box B

64 Waterman Street

Providence, RI 02912

and NBER

Brian_Knight@brown.edu

Maria Mercedes Ponce de Leon

Brown University

64 Waterman St

Providence, RI 02912

maria_ponce_de_leon@brown.edu

Ana Tribin

UNDP-RBLAC

Ana.tribin@undp.org
\end{abstract}

This paper investigates the link between gender and crime using information from a gender-based lockdown policy in Bogota Colombia during the pandemic. Under the policy, men were allowed out on odd days and women on even days, and we investigate whether overall crime rates differed and whether crime was lower on women-only days. We compare crime in Bogota to other cities and, within Bogota, the gender-based lockdown period to weeks with other lockdown policies. Our key findings are that crime rates are higher during the gender-based lockdown policy and that this is driven by more crime involving male victims and on men-only days. There is no evidence that higher crime on men-only days is offset by less crime on women-only days. The higher crimes on men-only days is driven by robbery, stolen cars and motorcycles, and homicides. We find higher sexual crimes on women-only days and an increase in domestic violence on both types of days. Taken together, our results suggest that gender segregation, if anything, tends to 


\section{Introduction}

This paper investigates the role of gender segregation in patterns of criminality. This research is motivated by the fact that men are generally more prone to violence than women. That is, men commit significantly more offences compared to women and they are also the majority of victims for most crimes, with the exception of domestic and sexual violence (Smith, 2015; Steffensmeier et al. 2005; Buzawa et al., 2017). Given that men commit more crimes than women, advocates of gender segregation argue that it can reduce crimes against women. For example, many cities, such as Mexico City, have adopted women-only trains and buses to protect women from male harassment, and Aguilar et al (2019) find that the segregation program in Mexico does reduce sexual harassment towards females but increases non-sexual aggression incidents among males 1 Another example involves gender segregation in schools, and there is evidence that disruption and violence among male students increases when reducing the proportion of girls in the classroom (Lavy and Schlosser, 2011; Gee and Cho, 2014). Outside of these settings, however, there is little quantitative evidence on the effect of gender segregation on violence and crime.

To investigate possible links between gender segregation and crime, we study crime patterns in Bogota Colombia during a gender-based COVID lockdown in the spring of 2020. Under the policy, coined Pico y Genero (peak and gender), only men were allowed to leave their homes on odd-numbered days, while women were permitted to do so on even-numbered days. Using daily crime data, and comparing Bogota to other cities in Colombia that did not have a gender-based lockdown, we investigate overall crime rates during this period and crime rates on men-only days, relative to women-only days. In this way, this experiment allows us to examine whether gender segregation increases or decreases crime by analyzing differences between women-only days and men-only days, differences between crimes involving male victims and crimes involving female victims, and differences across types of crimes.

We begin by documenting that the gender-based lockdown mattered, in the sense there is evidence consistent with more females outside of their homes on women-only days and more males outside on men-only days. Building upon this, we then investigate patterns of crime on men-only days versus women-only days. Our key finding is that crime rates are much higher on men-only days in Bogota, relative to the time period without a gender-based lockdown and

\footnotetext{
${ }^{1}$ https://www.nytimes.com/2008/02/11/world/americas/11mexico.html
} 
relative to other cities without a gender-based lockdown. In particular, crime increases by 24 percent on men-only days. Moreover, this increase is not offset by a reduction in crimes on women-only days, meaning that crime tended to be higher overall as a result of the genderbased lockdown. The increase in crime on men-only days is driven by an increase in crimes with male victims, which increases by 34 percent on men-only days. We also find no evidence of a reduction in crimes against females resulting from gender segregation; if anything, crimes with female victims tend to increase during the policy. Investigating the types of crimes, we find increases in robbery, stolen cars and motorcycles, and homicides on men-only days. On women-only days, by contrast, we find higher sexual crimes. Finally, we document an increase in domestic violence on both men-only and women-only days.

The paper proceeds as follows. We next review the relevant literature and then provide a more detailed overview of the setting. We then describe our empirical approach and data. Following a presentation of our empirical results, the final section concludes.

\section{Related Literature}

This paper comes at the intersection of two literatures, one on crime and gender and another on crime and COVID lockdowns. On the latter, recent literature finds that, except for domestic violence, most crimes decreased as a result of lockdowns. Using data from 25 large US cities, Abrams (2020) shows that, following stay-at-home orders, both criminal incidents and arrests fell considerably, with the effect coming mainly from fewer drug crimes, theft, residential burglaries, and most violent crimes. Similarly, Boman and Gallupe (2020) compare crime to the pre-pandemic year and, using calls for service by law enforcement, found a decline in crime rates for the US. They document that the decrease was driven by minor offenses committed in groups, while more severe crimes, which are typically committed solo either increased (partner violence) or remained constant (homicides) ${ }^{2}$ Estevez-Soto (2020) studies crime patterns in Mexico City during the pandemic, comparing observed crime to forecasts based on pre-pandemic trends. He finds a significant reduction in most crimes, partly attributed to a decrease in urban mobility and under-reporting, but no change in domestic violence, which was already increasing before the pandemic. Other studies have shown that quarantine led to a reduction in crimes that are committed on the street (Ashby 2020; Campedelli et al.

\footnotetext{
${ }^{2}$ Exploiting data from Philadelphia, the author argues that the drop is not due to a reduction in reporting.
} 
2020; Mohler et al. 2020; Payne et al. 2020 and Cheung and Gunby, 2020) but an increase in those that occur within the home, such as domestic violence. In particular, several papers document an increase in calls to report domestic violence: Agüero (2020) for Peru, PerezVincent et al. (2020) for Argentina, Leslie and Wilson (2020) and Chalfin (2020) for United States, Ravindran and Shah (2020) for India, and Mohler et al (2020), who using data from Los Angeles and Indianapolis, finds that domestic violence increased in both cities due to a rise in the opportunities for incidents stemming from people being at home more. The link between the increase in certain crimes and subsequent arrests has not been clear. Miller at al (2020), using data from Los Angeles, find that, while domestic violence calls for service increased after the city first went into lockdown, arrests for this crime decreased during that same time. Bullinger et al (2020) find similar results for Illinois, where, even with domestic violence calls on the increase following the stay-at-home order, reported crimes and arrests for this particular crime fell considerably (arrests fell by over 26 percent). During the pandemic, the police force had to take on new responsibility to ensure public safety while working with limited resources. These papers highlight some possible unintended consequences of policing priorities having to shift in order to enforce the new COVID-related measures.

Concerning the link between gender and crime, the literature has documented a gender gap in crime, by which men commit more crimes than women (Steffensmeier and Allan (1996)). More recently, researchers have studied the evolution of this gender gap as well as explanations for the fact that it appears to be closing. Lauritsen, Heimer, and Lynch (2009) use data from the US between 1973 and 2005, documenting that the gap for aggravated assault, robbery, and simple assault has narrowed as a result of male crime rates decreasing more quickly than female crime rates. De Coster and Cornell (2010), using survey data from the US, provide evidence that depression seemed to exacerbate the effect of anger over committing a crime, but for males only. Hence, differences in crime rates between genders result from differences in how the two genders process certain emotions and how these emotions interact. Using data from Colombia, Khanna et al (2021) find that the probability of getting arrested increase after mass layoffs but only for men. Chetty et. al. (2016) document that boys growing up in high crime neighborhoods tend to work less than girls growing up in comparable neighborhoods and suggest that this might involve substitution from formal employment into crime. Couttenier et al (2019) show that male adult asylum seekers exposed to civil conflict during childhood 
have a higher probability of committing violent crimes, while this effect is absent for women. Damm and Dustmann (2014) find strong evidence that early exposure to neighborhood crime increases the probability of subsequent criminal convictions for males but not for females.

Our paper contributes to these two literatures by studying the effects of crime during a lockdown that created gender segregation, with men allowed out on some days and women out on others. This setting provides us with a unique lens through which to study the relationship between gender, segregation by gender, and patterns of crime.

\section{Background}

The coronavirus outbreak officially started in Colombia on March 6, 2020, when the first case of COVID-19 was diagnosed in Bogota, the capital city. In the span of five days, between March 12 and March 17, all public events were banned, airports and all transportation station were closed until further notice, and the President of Colombia declared a national state of emergency. Bogota's mayor then implemented a voluntary lockdown from March 20 to March 23. This initiative was followed by the President issuing a national shelter-in-place order on March 24. While this was initially in place until April 13, it was subsequently extended but with a re-opening of the manufacturing and construction sectors starting on April 27. This was followed by a further loosening of restrictions on May 11, when even more areas of commerce started to operate.

In Bogota specifically, the city was under lockdown from March 20 to April 13. Starting on April 13, there was an extension of the quarantine but Bogota implemented a gender-based restriction on mobility called "pico y genero", translated as "peak and gender" 3 Under this policy, women could go outside for critical needs (i.e., banking, grocery shopping, medical appointments) on even-numbered calendar days, while men were permitted to go outside on odd-numbered calendar days $4^{4}$ Anyone caught breaking the rule was subject to a fine of USD240, about the minimum monthly salary in Colombia. Violators must pay half the fine within five days or face an appearance in court.

\footnotetext{
${ }^{3}$ The measure was inspired by the Colombian capital's "pico y placa" program ("peak and plate"), a policy designed to reduce traffic congestion and pollution.

${ }^{4}$ To the best of our knowledge, no other cities in Colombia implemented gender-based lockdown. Some other cities instead applied restrictions on entry to stores and banks based on the last digit of the identification card. See https://www.eltiempo.com/colombia/otras-ciudades/ pico-y-cedula-pico-y-genero-conozca-la-restriccion-en-cada-ciudad-de-colombia-484516
} 
There were exemptions from the gender-based lockdown for people working in critical industries, such as food service and health care. Given these exemptions, the policy did not lead to complete gender segregation, with some women allowed out on men-only days and, likewise, some men allowed out on women-only days, all for work-related purposes. Importantly, females were thus still potentially threatened by male perpetrators on womenonly days.

On April 27, as noted above, the President mandated a loosening of restrictions to restart some economic activity. The construction sector, which is highly male (94 percent), was re-opened. Thus, adding to the original exemptions, there were even more males out on women-only days during the second half of pico y genero, relative to women-only days during the first two weeks of pico y genero. Family courts also re-opened, allowing victims of domestic violence to report crimes. On May 11, even more sectors were allowed to re-open. The mayor of Bogota responded by ending the pico y genero policy, noting that it was now impossible to enforce gender-based mobility. Therefore, on May 11, the pico y genero restriction ended.

To summarize, on March 20, the country moved to voluntary quarantine followed by mandatory national quarantine on March 23. The city of Bogota started the gender-based lockdown policy on April 13, and some sectors, such as construction, began re-opening on April 27. Finally Bogota ended pico y genero on May 11.

\section{Data}

Our crime data are based upon administrative records from the National Police of Colombia 5 These data are based on crime incidents and, for the purposes of our analysis, we exploit information on the city in which the crime occurred, the exact date of the crime, and the gender of the victim. We aggregate these data to the city-date level. For comparability with Bogota, the most populated city in Colombia, we drop small cities, those with population less than 5,000 6 This leaves us with a sample of 897 municipalities.

In terms of constructing our sample period, the pico y genero policy lasted 28 days, with the first day on April 13 and the last day on May 10. Thus, we have 14 women-only days and 14 men-only days. As a comparison period, we focus on the three weeks before the policy,

\footnotetext{
${ }^{5}$ These data were provided through a right of petition.

${ }^{6}$ Population measures are based upon estimates from the National Administrative Department of Statistics (DANE) as of 2020
} 
from March 23 until April 12, and the three weeks after the policy, from May 11 until May 31. Thus, in total, our sample period consists of 70 days.

To investigate whether pico y genero mattered, we also use mobility data from Google, from which we gathered information on mobility in Colombia at the department level, which are more aggregated than cities, but also for the city of Bogota specifically. These data provide information on mobility day-by-day and separately for six place categories: Grocery and Pharmacy, Parks, Transit Stations, Retail and Recreation, Residential and Workplaces. Mobility measures are constructed with respect to a baseline, defined by Google as the median value for each specific day of the week during the pre-lockdown period, covering January 3 , 2020 until February 6, 2020.

\section{$5 \quad$ Hypotheses and Methods}

We examine the effects of pico y genero on total crimes, crimes with female victims, crimes with male victims, and types of crimes. Our hypotheses are motivated by the fact that crimes are disproportionately committed by men but that, as we will demonstrate below and across all types of crimes, roughly one-half of victims are female in Bogota and roughly one-half are male. Given this, we hypothesize that crimes with male victims should increase on menonly days. This is driven by the fact that there are both more potential offenders and more potential male victims on these days. In terms of crimes with female victims, predictions are less clear. On men-only days, there are more potential perpetrators but fewer potential female victims. Thus, crimes with female victims could either increase or decrease on men-only days. Likewise, on women-only days, there are fewer potential perpetrators but more potential female victims, leading again to an ambiguous prediction. An additional complicating factor is that females out on women-only days might be more susceptible to crimes by male strangers since they cannot have male companions. This lack of male companions could increase crimes against females on women-only days. In terms of overall crimes, aggregated across both male and female victims, we hypothesize that crime rates should be higher on men-only days since the number of potential victims is similar but there are more potential perpetrators. In terms of women-only days, we do not have a clear prediction. While there are fewer potential perpetrators, females who are outside might be more susceptible to crime for the reasons 
described above.

To investigate these hypotheses, we develop a difference-in-differences identification strategy, exploiting the fact that the Pico y Genero policy only took place in Bogota and only during four weeks of the broader lockdown period. Hence, to estimate the effect of gender segregation on crime, we will compare reported crime in Bogota versus the rest of Colombia for three specific time periods: men-only days, women-only days, and the non-gender lockdown period, covering the three weeks before pico y genero and the three weeks after. More specifically, throughout the empirical analysis, we estimate the following regression model:

$Y_{c, t}=\beta_{1}$ Bogota $X$ pico $X$ men only $+\beta_{2}$ Bogota $X$ pico $X$ women only $+\beta_{3}$ Bogota $X$ odd $+\mu_{t}+\gamma_{c}+\epsilon_{c, t}$

Where $Y_{c, t}$ represents crime outcomes in city $c$ on day $t, \mu_{t}$ and $\gamma_{m}$ correspond to time and municipality fixed effects, respectively, and $\epsilon_{m, t}$ represents the unobservable factors influencing reported crime in city $c$ on date $t$. Our key regressors include Bogota X pico X men only, which captures excess crime in Bogota during the policy on days when only men can go out, relative to other days outside of the pico y genero period, and Bogota $X$ pico $X$ women only, which captures excess crime in Bogota during the policy on days when only women can go out, again relative to other days outside of the pico y genero period. Finally, Bogota $X$ odd captures any differences in crime between odd days and even days in Bogota. Without this control, any such differences between odd days (men only) and even days (women only) in Bogota would be loaded onto Bogota X pico X men only. Our crime outcomes measures $\left(Y_{c, t}\right)$ include the natural $\log$ (plus one) of the number of crimes in city $c$ on date $t$, the natural $\log$ (plus one) of the number of crimes involving male victims in city $c$ on date $t$, and the natural $\log$ (plus one) of the number of crimes involving female victims in city $c$ on date $t$. We also later investigate arrests and types of crimes.

While our analysis is based upon a triple interaction, note that we cannot separately control for Bogota X pico since this would be collinear with Bogota X pico X men only, Bogota X pico X women only, and the Bogota city fixed effect. Said differently, our strategy involves measuring the effects of pico y genero on crime rates but, importantly, allowing for heterogeneity between men-only days and women-only days. Likewise, we cannot control separately for Bogota $X$ even since this would be collinear with Bogota $X$ odd and the Bogota 
city fixed effect. Finally, we cannot separately control for pico X men only and pico X women only as these are date-specific and thus already fully captured in the date fixed effects.

Given that we only have one treatment city, Bogota, and only 28 days during the pico y genero period, p-values from conventional large sample inference techniques are likely to be understated. Given this, we calculate p-values via permutation methods. In particular, we run separate placebo regressions in which we assume that each of the cities in Colombia other than Bogota adopted pico y genero. Running these placebo regressions separately for each city gives up a placebo distribution of effects, and, following standard techniques, we calculate p-values via the share of regressions in which the absolute value of the placebo coefficient exceeded the corresponding coefficient from the regression using Bogota as the pico y genero city. As a robustness check, we also run placebo regressions in which we hold Bogota fixed as the treatment city but instead permute the distribution of dates, randomly assigning 14 days from our sample period to be pico y genero odd days and a different 14 days from our sample period to pico y genero even days.

\section{Did the Lockdown Matter?}

Before investigating the effects of the lockdown on patterns of crime, we first provide some evidence that the gender-based lockdown policy mattered. While we lack formal data on mobility by gender during pico y genero, we provide three pieces of evidence consistent with either enforcement of pico y genero or changes in gender-based mobility on men-only days versus women-only days.

First, according to anecdotal evidence, the measure was heavily enforced. In particular, during the first two days of pico y genero, police sanctioned 104 women and 610 men in Bogota for violating the gender-based mobility guidelines.7 Moreover, as mentioned above, the fine of USD240 was significant, representing the minimum monthly salary in Colombia at current. Thus, there were strong incentives to follow the gender-based lockdown policy.

Second, we use mobility data to investigate whether our results are consistent with those in Woskie and Wenham (2021), who study a similar policy in Panama and show that overall mobility was lower on women-only days. Given this, we investigate whether overall mobility in Bogota was lower on women-only days. To do so, we use Google mobility data and com-

\footnotetext{
${ }^{7}$ See https://www.nytimes .com/2020/04/15/world/americas/virus-colombia-bogota-men-women.html 
pute mobility in Bogota relative to the rest of Colombia. We aggregate the 70 days in our sample period into six categories: odd days pre-policy, even days pre-policy, men-only days (odd) during pico y genero, women-only days (even) during pico y genero, odd days after the policy, and even days after the policy. As shown in Figure 1, we find that, consistent with Wolskie and Wenham (2021), mobility was indeed significantly lower on women-only days, relative to men-only days, during pico y genero, relative to the rest of Colombia for three mobility categories: retail and recreation, parks, and grocery and pharmacy. We find no such differences between even days and odd days before the pico y genero period started or between even days and odd days after the pico y genero policy ended. We also find lower mobility on women-only days during pico y genero for workplace and transit. These differences are smaller, however, presumably due to exemptions for certain sectors and the lesser degree of discretion associated with employment-related mobility. Finally, we find more people at home, as reflected in the residential category, on women-only days, relative to men-only days, during pico y genero, relative to the rest of Colombia. These differences are also small, however, presumably reflecting the significant amount of time spent at home at baseline. To conclude, we find that mobility was lower on women-only days, relative to men-only days. Although we lack formal evidence on the mechanism, we conjecture that females were hesitant to go out alone in Bogota, a high crime city, and especially so during the lockdown policy, when the streets were relatively deserted 8

Third, we use the data on crime reports, which include information on the gender of the victim, to compute the share of female victims in Bogota on each day during the lockdown period. As shown in Figure 2 and, as expected, there were not significant differences between odd days and even days prior to pico y genero in terms of the fraction of female victims, which averages around one-half. Likewise, after the end of pico y genero, there are no obvious differences between odd days and even days in terms of the fraction of female victims. During the pico y genero period, however, the fraction of female victims spiked on women-only days, averaging 54.5 percent, while this fraction dropped significantly on men-only days, averaging 44.1 percent. Outside of the pico y genero period, the share of female victims was similar across odd days and even days, averaging 50.6 percent on even days and 49.1 percent on odd

\footnotetext{
${ }^{8}$ This hypothesis is in line Harriott (2003), who found that, despite men being more likely to be more victimized in Jamaica, females exhibit higher levels of fear of being victimized. Given this, females might take more precautions to prevent this perceived high risk.
} 
days. Thus, the fraction of females victimized on women-only days was roughly 10 percentage points higher, representing a 20 percent increase, than the corresponding fraction on men-only days, and we find no such differences between odd days and even days outside of the pico y genero policy.

\section{Crime Results}

Having established that the lockdown mattered for gender mobility, we next investigate whether or not gender segregation increased reported crime, whether crime was higher on male-only days, how the distribution of the gender of the victims shifts, and how the results vary across different types of crimes. We begin with Figure 3, which reports the total number of crimes by day in Bogota during the three weeks leading up to gender segregation, the four weeks of pico y genero, and the three weeks after the policy ended. As shown, reported crime was relatively low during the period prior to the gender-based lockdown, and there were not significant differences between odd days and even days. Starting on April 13, by contrast, there is a large spike in reported crimes, and this is clearly driven by increases on men-only days. When some sectors re-opened on April 27, the differences between men-only days and women-only days remain but the size of these differences shrinks, presumably reflecting the fact that many males were out on women-only days due to employment-related mobility. Overall, reported crime rose during the pico y genero period. Following the end of gender segregation, crime rates were flat for the subsequent three weeks and, again, there are not obvious differences between odd days and even days.

To more formally investigate these patterns, we next turn to our regression results. Consistent with the results in Figure 3, Table 1 documents that, during the policy, crime in Bogota was higher on men-only days during pico y genero, relative to odd days both before and after the gender segregation policy. In particular, reported crime increased by 24 percent on these men-only days, and this difference is statistically significant at conventional levels, with a p-value of 4.69 percent. As shown in the second row, there is no evidence that this higher crime on men-only days was offset by lower crime on women-only days, as crime is actually four percent higher, a difference that is not statistically different from zero. As shown in the second column, this large increase in crime on men-only days is driven by crimes involving 
male victims, as hypothesized above. In particular, crimes involving male victims increase by 34 percent on men-only days, and this difference is statistically significant at conventional levels, with a p-value of 0.22 percent. As shown in the second row of column 2 , there is no change in crimes involving male victims on women-only days. Finally, as shown in column 3, there are not clear patterns for crimes involving female victims, which tend to go up by 14 percent on both men-only and women-only days, although neither of these increases is statistically significant at conventional levels. As noted above, there are opposing forces when studying crimes involving female victims, as crime could increase on women-only days, due to more potential female victims, or on men-only days, due to more potential male offenders.

To investigate the robustness of our permutation-based approach to inference, we next present p-values in which inference is based upon permutations of dates rather than permutations of municipalities. In particular, we take the 70 days of our sample period and randomly assign 14 days to be designated as men-only and pico y genero and 14 days to women-only and pico y genero. For the remaining 42 days, 22 days are assigned to be non-pico odd days and the remaining 20 days are assigned to be non-pico even days.9 We repeat this process 1,000 times, and p-values report the fraction of cases in the placebo regressions in which the absolute value of the placebo coefficient exceeded the coefficient using the actual date formulation.

As shown in Appendix Table 1, the p-values from this regression are broadly similar to those in Table 1. In particular, the p-value for all victims on men-only days increases slightly, from 4.69 percent to 6.00 percent, and the p-value for male victims on men-only days increases from 0.22 percent in Table 1 to 2.30 percent in Table A.1. Thus, our key results remain statistically significant at conventional levels when using inference based upon permutations of dates rather than permutations of municipalities.

We next investigate which types of crimes are driving the increase in crimes on men-only days, breaking crimes into the following categories: robbery, store or house robbery, stolen car or motorcycle, intra-family violence (i.e., domestic violence), sexual crimes, injuries, threats, and homicides. As shown in Table 2, we find that the increase in crimes on men-only days is driven by increases in robbery, stolen cars or motorcycles, and homicide 10 These types of

\footnotetext{
${ }^{9}$ Given that March and May both have 31 days and that our sample period both begins and ends on an odd day, there are more odd days than even days in our sample.

${ }^{10}$ Note that the number of municipalities in the sample varies across types of crimes. This is due to us dropping municipalities that do not report a given type of crime over the 70-day sample period. Since there is no
} 
crimes tend to be committed by males, and most victims of homicides are also male. These findings suggest that a men-only environment might lead to more aggression and more crimes involving both male victims and male perpetrators, with a less secure environment overall. In terms of women-only days, we find a large increase in sexual crimes, which disproportionately involve female victims. This is presumably driven by the fact that there are more potential female victims on women-only days, and, as noted above, these females cannot have male companions, making them even more vulnerable to male perpetrators.

In terms of intra-family violence, which has been the focus of many papers in the literature, we find increases on both men-only days and women-only days, with increases of 18 percent on both types of days. We conjecture that the increase in intra-family violence on womenonly days days is driven by increased reporting on women-only days associated with the courts re-opening during the second half of pico y genero, as noted above. The increase on men-only days, by contrast, is likely driven by women not being able to escape their homes when threatened by their partners. Consistent with this interpretation, Appendix Figure 1 documents large spikes in domestic violence on men-only days during the first half of pico y genero but large spikes on women-only days during the second half, when the courts re-opened. Taken together, and combined with the increase in sexual crimes on women-only days during pico y genero, this finding of a higher rate of domestic violence under pico y genero suggests that gender segregation outdoors, conversely, might lead to a less secure environment overall for females.

In Appendix Table 2, we next investigate whether arrests tend to move in tandem with these results involving reported crime ${ }^{11}$ As shown, we find that, if anything, the results are reversed, with fewer arrests under gender segregation, as shown in the first column. This result is driven by fewer arrests of male suspects on women-only days, as shown in the second column. We also find a corresponding reduction in arrests involving female suspects on menonly days, as shown in the final column.

Why do crimes tend to increase during pico y genero while arrests tend to decline? We offer two potential explanations for this divergence. First, the efforts of police in Bogota may have been diverted from arresting criminals to enforcing the pico y genero policy. Indeed, and

within-municipality variation in these cases, one cannot estimate a placebo coefficient for these municipalities.

${ }^{11}$ The number of municipalities in this analysis, 731, is a bit lower than the number of municipalities in Table 1. This is due to the fact that some small municipalities do not report any arrests over the 70-day sample period. 
as noted above, over 700 individuals in Bogota were cited for violating pico y genero during just the first two days of the policy. Second, there was a precautionary 14-day quarantine of roughly 20 percent of the police force in Bogota beginning on April 8, just five days before the start of pico y genero. Moreover, a police officer in Bogota was suspected of infection around April 10, leading to additional quarantine of some police officers 12 Thus, the first part of the pico y genero period involved a smaller than typical police force in Bogota, potentially leading to fewer arrests, even during a period of increasing crime.

\section{Conclusion}

This paper studies a COVID-related quarantine measure established in Bogota, the capital city of Colombia, in which only women could go out on even days and only men could go out on odd days. This mobility restriction provides a unique lens through which to examine the relationship between gender and crime and the role of gender segregation in particular. We find that, if anything, crime tends to be higher under gender segregation, with higher crimes on men-only days and no corresponding reduction in crime on women-only days. This increase in crimes on men-only days is driven by crimes involving male victims, rather than by crimes involving female victims. Regarding the types of crimes, we find that the increase in crimes on men-only days is driven by robbery, stolen cars and motorcycles, and homicides. We find an increase in sexual crimes on women-only days and an increase in domestic violence on both men-only days and women-only days. Overall, we find little evidence that gender segregation reduces crime and, conversely, crimes tend to increase on men-only days, a result driven by crimes involving male victims.

\footnotetext{
${ }^{12}$ See https://www.rcnradio.com/bogota/el-20-de-la-policia-en-bogota-se-encuentra-en-aislamientopreventivo and https://www.policia.gov.co/sites/default/files/descargables/circular ${ }_{n} o_{0} 07 . p d f$
} 


\section{References}

[1] Abrams, D. (2020). COVID and crime: An early empirical look. U of Penn, Inst for Law Econ Research Paper, (20-49).

[2] Agüero, J. M. (2020). COVID-19 and the rise of intimate partner violence. World development, 137, 105217.

[3] Aguilar, A., Gutierrez, E. \& Soto, P. (2019). Benefits and Unintended Consequences of Gender Segregation in Public Transportation: Evidence from Mexico City's Subway System. Economic Development and Cultural Change. 10.1086/707421

[4] Ashby, M. P. (2020): "Initial evidence on the relationship between the coronavirus pandemic and crime in the United States," Crime Science, 9, 1-16.

[5] Boman, J. H., \& Gallupe, O. (2020). Has COVID-19 changed crime? Crime rates in the United States during the pandemic. American journal of criminal justice, 45(4), 537-545.

[6] Bullinger, L. R., Carr, J. B., Packham, A. (2020). COVID-19 and crime: Effects of stay-at-home orders on domestic violence (No. w27667). National Bureau of Economic Research.

[7] Buzawa, E. S., Buzawa, C. G., Stark, E. (2017). Responding to domestic violence: The integration of criminal justice and human services (5th ed.). SAGE

[8] Campedelli, G. M., \& Aziani, A. \& Favarin, S. (2020). Exploring the Immediate Effects of COVID-19 Containment Policies on Crime: an Empirical Analysis of the Short-Term Aftermath in Los Angeles. American Journal of Criminal Justice. 10.1007/s12103-02009578-6.

[9] Chalfin, A., Danagoulian, S., Deza, M. (2021). COVID-19 Has Strengthened the Relationship Between Alcohol Consumption and Domestic Violence (No. w28523). National Bureau of Economic Research.

[10] Cheung,L \& Gunby,P. 2020. "Crime and Mobility during the COVID-19 Lockdown: A Preliminary Empirical Exploration," Working Papers in Economics 20/17, University of Canterbury, Department of Economics and Finance. 
[11] Chetty, R., Hendren, N., Lina, F., Majerovitz, J., Scuderi, B. (2016). Childhood Environment and Gender Gaps in Adulthood. American Economic Review, 106(5), 282-88.

[12] Couttenier, M., Petrencu, V., Rohner,D., Thoenig, M. 2019. "The Violent Legacy of Conflict: Evidence on Asylum Seekers, Crime, and Public Policy in Switzerland." American Economic Review, 109 (12): 4378-4425.

[13] Damm, A. P., and Dustmann, C. 2014. "Does Growing Up in a High Crime Neighborhood Affect Youth Criminal Behavior?" American Economic Review, 104 (6): 1806-32.

[14] De Coster, S., \& Cornell Zito, R. (2010). Gender and general strain theory: The gendering of emotional experiences and expressions. Journal of Contemporary Criminal Justice, 26(2), 224-245.

[15] Estevez-Soto, P. R. (2020). Crime and COVID-19: Effect of changes in routine activities in Mexico City.

[16] Gee, K. A., Cho, R. M. (2014). The effects of single-sex versus coeducational schools on adolescent peer victimization and perpetration. Journal of adolescence, 37(8), 1237-1251.

[17] Harriott, A. (2003). Fear of criminal victimization in a reputedly violent environment. Social and Economic Studies, 35-71

[18] Khanna, G., Medina, C., Nyshadham, A., Posso, C., Tamayo, J. (2021). Job Loss, Credit, and Crime in Colombia. American Economic Review: Insights, 3(1), 97-114

[19] Lauritsen, J. L., Heimer, K., \& Lynch, J. P. (2009). Trends in the gender gap in violent offending: New evidence from the National Crime Victimization Survey. Criminology, 47(2), 361-399.

[20] Lavy, V., Schlosser, A. (2011). Mechanisms and impacts of gender peer effects at school. American Economic Journal: Applied Economics, 3(2), 1-33.

[21] Leslie, E., Wilson, R. (2020). Sheltering in place and domestic violence: Evidence from calls for service during COVID-19. Available at SSRN 3600646.

[22] Miller, A. R., Segal, C., Spencer, M. K. (2020). Effects of the COVID-19 Pandemic on Domestic Violence in Los Angeles (No. w28068). National Bureau of Economic Research. 
[23] Mohler, G., Bertozzi, A. L., Carter, J., Short, M. B., Sledge, D., Tita, G. E., ... \& Brantingham, P. J. (2020). Impact of social distancing during COVID-19 pandemic on crime in Los Angeles and Indianapolis. Journal of Criminal Justice, 101692.

[24] Payne, J., Morgan, A., Piquero, A. R. (2020). Covid-19 and social distancing measures in queensland australia are associated with short-term decreases in recorded violent crime.

[25] Perez-Vincent, S., Carreras, E., Gibbons, M., Murphy, T. E., Rossi, M. (2020). COVID19 Lockdowns and Domestic Violence: Evidence from Two Studies in Argentina (No. 143). Buenos Aires: Universidad de San Andres. doi, 10, 0002490.

[26] Ravindran, S., Shah, M. (2020). Unintended consequences of lockdowns: covid-19 and the shadow pandemic. NBER Working Paper, 27562.

[27] Smith G . (2014), 'Long-Term Trends in Female and Male Involvement in Crime', in R. Gartner and B. McCarhty, eds, The Oxford Handbook of Gender, Sex, and Crime, 139-57. Oxford University Press.

[28] Steffensmeier, D., \& Allan, E. (1996). Gender and crime: Toward a gendered theory of female offending. Annual review of sociology, 22(1), 459-487.

[29] Steffensmeier, D., Schwartz, J., Zhong, H., Ackerman, J. (2005). AN ASSESSMENT OF RECENT TRENDS IN GIRLS'VIOLENCE USING DIVERSE LONGITUDINAL SOURCES: IS THE GENDER GAP CLOSING?. Criminology, 43(2), 355-406. 
Figure 1: Mobility in Bogota Versus Rest of Colomiba

Retail and Recreation
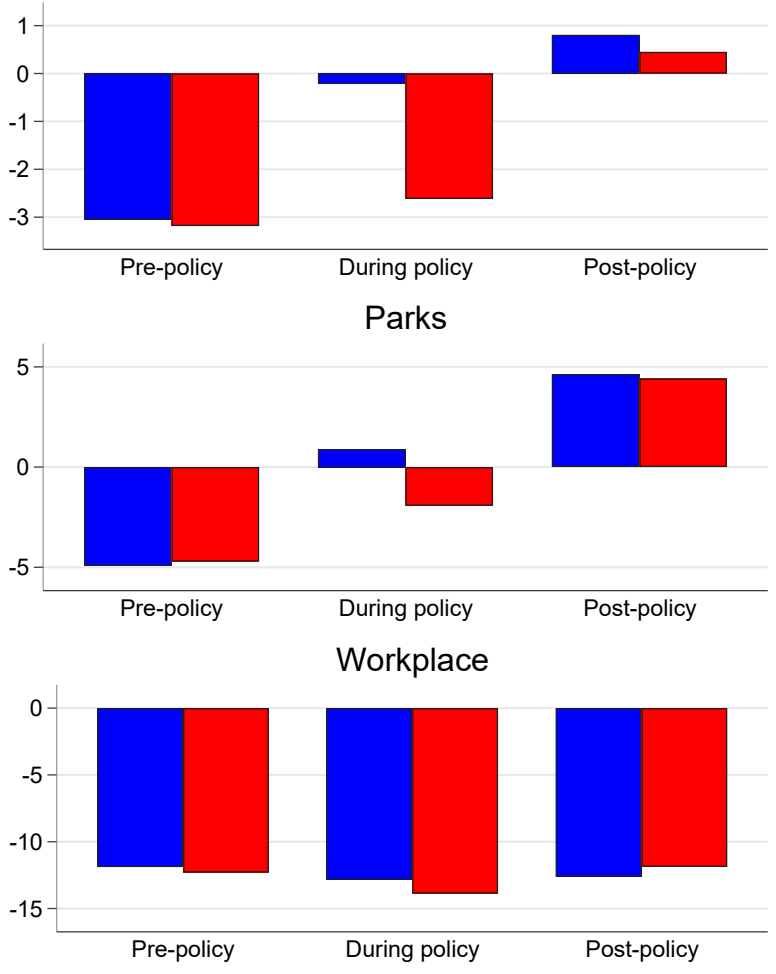

Grocery and Pharmacy
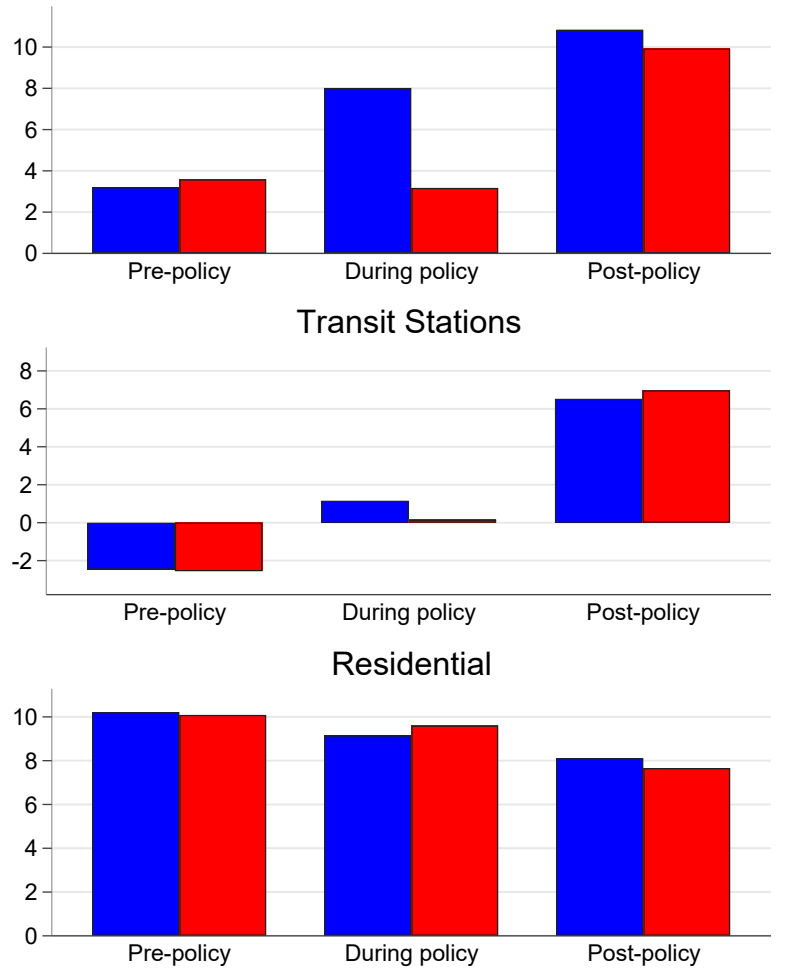

Men only

Women only 
Figure 2: Share of Female Victims in Bogota

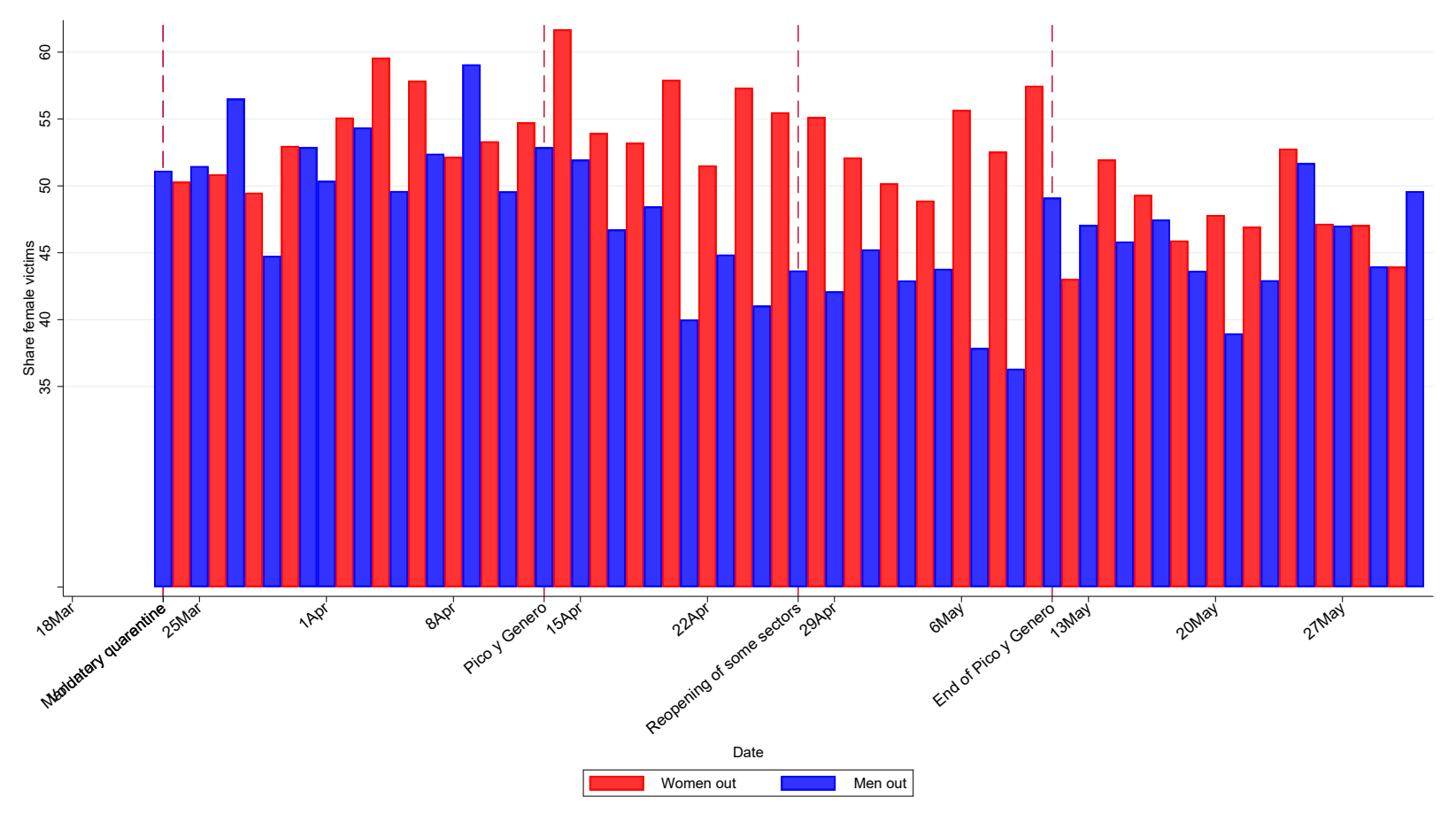

Figure 3: Crimes in Bogota

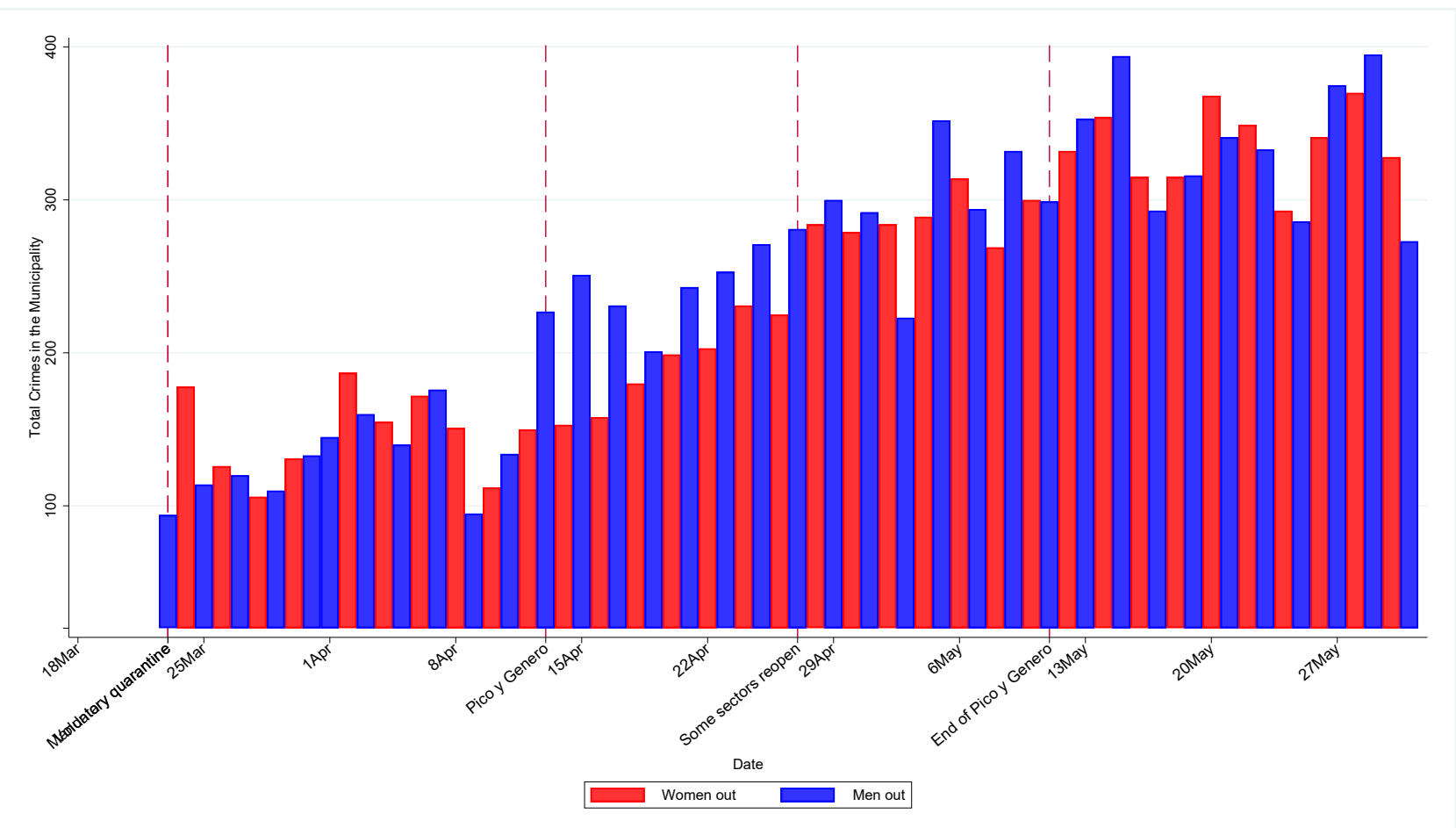


Table 1: Regression Results for Crimes in Bogota

\begin{tabular}{|c|c|c|c|}
\hline & all victims & male victims & female victims \\
\hline \multirow[t]{2}{*}{ Bogota X pico X men only } & $0.2410^{* *}$ & $0.3437^{* * *}$ & 0.1417 \\
\hline & $(0.0469)$ & $(0.0022)$ & $(0.1016)$ \\
\hline \multirow[t]{2}{*}{ Bogota X pico X women only } & 0.0408 & -0.0089 & 0.1427 \\
\hline & $(0.6864)$ & $(0.9219)$ & $(0.1038)$ \\
\hline municipal FE & $\mathrm{Y}$ & $\mathrm{Y}$ & $\mathrm{Y}$ \\
\hline day FE & $\mathrm{Y}$ & Y & $\mathrm{Y}$ \\
\hline municipalities & 897 & 897 & 897 \\
\hline dates & 70 & 70 & 70 \\
\hline total sample size & 62790 & 62790 & 62790 \\
\hline
\end{tabular}

notes: ${ }^{* * *}$ denotes 99 percent significance, ${ }^{* *}$ denotes 95 percent significance, ${ }^{*}$ denotes 90 percent significance. All regressions include Bogota $X$ even controls. Dependent variable is in natural logs. P-values from permutation tests in parantheses.

Table 2: Regression Results for Types of Crimes

\begin{tabular}{|c|c|c|c|c|c|c|c|c|}
\hline & robbery & $\begin{array}{c}\text { store or } \\
\text { house } \\
\text { robbery }\end{array}$ & $\begin{array}{c}\text { stolen car or } \\
\text { motorcycle }\end{array}$ & $\begin{array}{c}\text { intra-family } \\
\text { violence }\end{array}$ & $\begin{array}{l}\text { sexual } \\
\text { crimes }\end{array}$ & injuries & threats & homicide \\
\hline Bogota X pico X men & $0.4257^{* * *}$ & $0.1050^{*}$ & $0.4425^{* * *}$ & $0.1846^{* *}$ & 0.0171 & $0.2180^{* *}$ & $0.0975^{*}$ & $0.3221 * * *$ \\
\hline only & $(0.0046)$ & $(0.0870)$ & $(0.0000)$ & $(0.0400)$ & $(0.6134)$ & $(0.0257)$ & (0.0919) & $(0.0027)$ \\
\hline Bogota $X$ pico $X$ & -0.0546 & $-0.1911 * *$ & $0.1085^{*}$ & $0.1772 *$ & $0.2862 * * *$ & $0.2394 * *$ & $0.1688^{* *}$ & 0.0071 \\
\hline women only & $(0.2511)$ & $(0.0302)$ & $(0.0780)$ & $(0.0538)$ & $(0.0035)$ & $(0.0227)$ & $(0.0188)$ & $(0.6504)$ \\
\hline municipal FE & $Y$ & $Y$ & $Y$ & $Y$ & $Y$ & $Y$ & $Y$ & $Y$ \\
\hline day FE & Y & Y & Y & Y & Y & Y & Y & Y \\
\hline municipalities & 220 & 564 & 283 & 725 & 570 & 662 & 534 & 370 \\
\hline dates & 70 & 70 & 70 & 70 & 70 & 70 & 70 & 70 \\
\hline total sample size & 15400 & 39480 & 19810 & 50750 & 39900 & 46340 & 37380 & 25900 \\
\hline
\end{tabular}

notes: ${ }^{* * *}$ denotes 99 percent significance, ${ }^{* *}$ denotes 95 percent significance, ${ }^{*}$ denotes 90 percent significance. All regressions include Bogota $X$ even controls. Dependent variable is in natural logs. P-values from permutation tests in parantheses. 
Figure A.1: Intrafamily Violence in Bogota

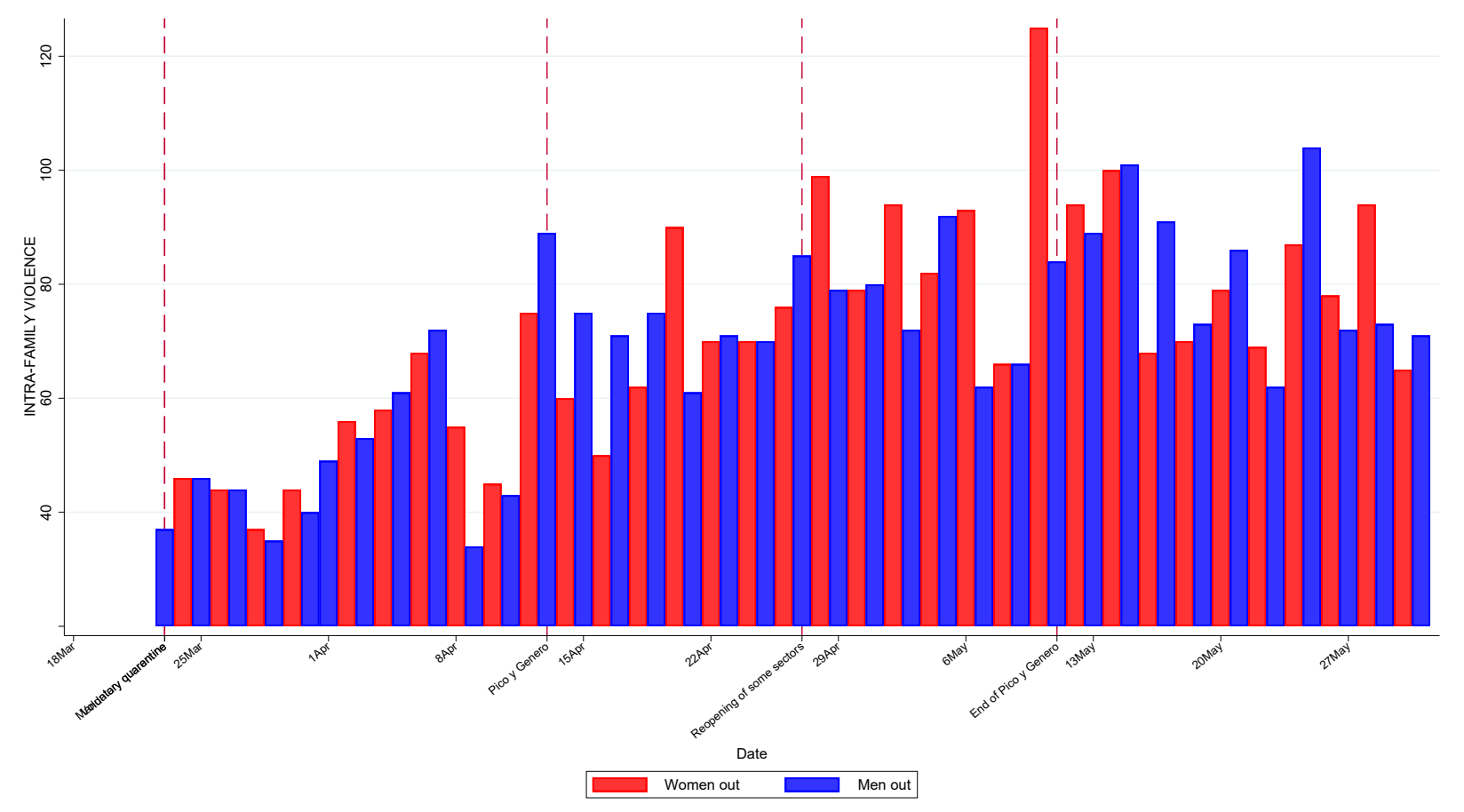


Table A.1: Robustness Check with Date Permutation

\begin{tabular}{|c|c|c|c|}
\hline & all victims & male victims & female victims \\
\hline \multirow[t]{2}{*}{ Bogota X pico X men only } & $0.2410^{*}$ & $0.3437 * *$ & 0.1417 \\
\hline & $(0.0600)$ & $(0.0230)$ & $(0.2530)$ \\
\hline \multirow[t]{2}{*}{ Bogota X pico X women only } & 0.0408 & -0.0089 & 0.1427 \\
\hline & $(0.7600)$ & $(0.9500)$ & $(0.2170)$ \\
\hline municipal FE & $\mathrm{Y}$ & $\mathrm{Y}$ & $\mathrm{Y}$ \\
\hline day FE & Y & $Y$ & $\mathrm{Y}$ \\
\hline municipalities & 897 & 897 & 897 \\
\hline dates & 70 & 70 & 70 \\
\hline total sample size & 62790 & 62790 & 62790 \\
\hline
\end{tabular}

notes: ${ }^{* * *}$ denotes 99 percent significance, ${ }^{* *}$ denotes 95 percent significance, ${ }^{*}$ denotes 90 percent significance. All regressions include Bogota $X$ even controls. Dependent variable is in natural logs. P-values from permutation tests in parantheses. 1000 permutations.

Table A.2: Regression Results for Arrests in Bogota

\begin{tabular}{|l|ccc|}
\multicolumn{1}{c}{} & all suspects & male suspects & female suspects \\
\hline Bogota X pico X men only & -0.1189 & -0.0892 & $-0.2507^{* * *}$ \\
& $(0.1658)$ & $(0.2493)$ & $(0.0014)$ \\
Bogota X pico X women only & $-0.2866^{* *}$ & $-0.3541^{* *}$ & -0.0294 \\
& $(0.0178)$ & $(0.0110)$ & $(0.2411)$ \\
\hline municipal FE & $Y$ & $Y$ & $Y$ \\
day FE & $Y$ & $Y$ & $Y$ \\
municipalities & 731 & 731 & 731 \\
dates & 70 & 70 & 70 \\
total sample size & 51170 & 51170 & 51170 \\
\hline
\end{tabular}

notes: ${ }^{* * *}$ denotes 99 percent significance, ${ }^{* *}$ denotes 95 percent significance, ${ }^{*}$ denotes 90 percent significance. All regressions include Bogota $X$ even controls. Dependent variable is in natural logs. P-values from permutation tests in parantheses. 